\title{
Cellosaurus micro-review 1: cellonauts, spacefaring cell lines
}

BAIROCH Amos

University of Geneva, Switzerland and SIB - Swiss Institute of Bioinformatics

CMU; 1, Rue Michel Servet; 1211 Geneva 4; Switzerland

amos.bairoch@sib.swiss

Version 1.0, June 252019

Abstract: This micro-review is intended to provide an up to date list of the cell lines that have flown in space, starting with HeLa in 1960. We coin a new term, cellonaut for cell lines that have been sent in earth orbit. As of June 2019, we were able to identify 52 different celllonauts. Cell lines that are cellonauts are annotated as such in the Cellosaurus.

\section{Introduction: the HeLa space saga}

In the book that Rebecca Skloot wrote [Skloot, 2010] on the HeLa cell line ( $\mathrm{CVCL}$ 0030) and the woman from who it was established, Henrietta Lacks, it is stated that "Henrietta's cells went up in the second satellite ever in orbit, which was launched by the Russian space program in 1960, and almost immediately afterward, NASA shot several vials of HeLa into space in the Discoverer XVIII".

While it is true that HeLa was the first cell line to go to space, the book takes some liberty with the true space exploration career of HeLa which we tried to reconstruct. HeLa was flown in the 1960s on at least 7 different Soviet space missions [Dickson, 1991]. The first one took place on the $19^{\text {th }}$ to $20^{\text {th }}$ of August 1960, HeLa, along with some bacterial and phage cultures, plant seeds and rabbit and human skin samples shared passenger space with two dogs, Belka and Strelka on the Korabl-Sputnik-2 [W01] spacecraft (also known as Sputnik-5). Skloot most probably confused KorablSputnik-2 with Sputnik-2 [W02], which was the second man-made satellite to make it to earth orbit. It was launched on November 3, 1957 and did carry a passenger, but it was not HeLa, but Laika, a dog that died a few days later. From table 3 in [Rees and King-Hele, 1963] we estimate that Korabl-Sputnik-2 was the $30^{\text {th }}$ artificial satellite. Thus HeLa started its space career quite early in the history of space exploration but not as early as stated by Skloot.

The following year HeLa flew with Yuri Gagarin on Vostok-1, the first manned spaceflight. This was followed by four other manned missions: Vostok-4 in 1962, Vostok-5 and Vostok-6 in 1963 and Voskhod-1 in 1964. HeLa also travelled along with some tortoises [W03] on Zond-5 in 1968, an unmanned mission that was the first one that achieved a flyby of the moon followed by a successful return to earth. 
HeLa flew on the American satellite Discoverer XVIII [W04] which was launched on December 7, 1960. Three days later it ejected a capsule that was recovered in midair near Hawaii by a military transport plane. While the capsule was carrying a scientific experiment package, it real aim was to bring back film packs. Discoverer XVIII was part of a then classified CIA photographic surveillance system, the Corona program [W05]. The biological samples on Discoverer XVIII [Katzberg, 1962] were sealed in individual glass ampules. The paper states that "Seven human cell lines were employed. Five of these were normal, definitive representatives of the three embryonic germ layers, and two were of neoplastic origin." The "cell lines" are listed as: "Ectodermal: Amnion, Conjunctiva, Sternal marrow, Synovia; Mesodermal (neoplastic cell lines): Monocytic leukemia, Hela; Endodermal: Embryonic lung". It is most probable that the terminology "cell line" for the six non-HeLa samples is incorrect and most probably refers to primary cells.

Skloot book does not cover the second part of HeLa career in space which we tried to reconstruct. After a long hiatus, HeLa returned to space, sent by a Japanese research group [Ohnishi et al, 2002] on two missions, one on the Russian Mir space station for 41 days in 1997 and the other on the American Shuttle flight STS-89 in 1998 for 9 days, both to study the effect of space radiation on DNA damage. Finally it also went to the International Space Station (ISS) in 2006 but under an "alias" as the experimenters [Meloni et al, 2011] thought that they were studying a leukemia cell line but were in fact using a HeLa contaminated culture (see the results section).

\section{Methodology, scope and terminology}

While the space story of HeLa is interesting, it is by far not the only cell line to have made it to space and we wanted, in this micro-review to establish an up to date list of spacefaring cell lines. To establish this list we first started with two useful reviews published in the 1990s [Dickson, 1991; Moore \& Cogoli, 1996]. But it was necessary to dig a bit deeper, on one hand to find out which cell lines have been to space in the more than 20 years that elapsed since the second review was published but also to uncover the exact identity of the cell lines that are mentioned in these two reviews. To complete the list we carried out a large panel of searches on Google Scholar, PubMed and Europe PMC, the various European Space Agency (ESA), NASA and China National Space Science Center servers, the GeneLab Data System [Ray et al, 2019], a database of omics data generated during space flights and the Erasmus Experiment Archive [lsakeit et al, 2004], a database of ESA funded and co-funded experiments.

It is important to state that this micro-review only concerns itself with cell lines that have at least orbited earth once thus excluding cell lines that have flown on airplane parabolic flights, sounding rockets or stratospheric balloons. We have decided to coin a new term, 'cellonaut', for such space-faring cell lines. 
While digging deeply in publication relevant to cellonauts we encountered cell lines that were not yet in the Cellosaurus [Bairoch, 2018], we created new Cellosaurus entries for these entities. We also implemented a new "Group" comment "Spaceflown cell line (cellonaut)" that was retrofitted to all the cell lines described in this review. Thanks to these developments you can, on the ExPASy server, obtain the list of all cellonauts in the Cellosaurus using the following query: https://web.expasy.org/cgi-bin/cellosaurus/search?input=cellonaut

\section{Results}

Overall we could identify [Table 1] 52 different cellonauts that have flown on American, Chinese and Russian spaceflights as well as on the International Space Station (ISS). The identified cellonauts include 27 different human cell lines, 12 from mouse, 6 from rat, 4 from hamster and one each from pig (PICM-19; CVCL V146),

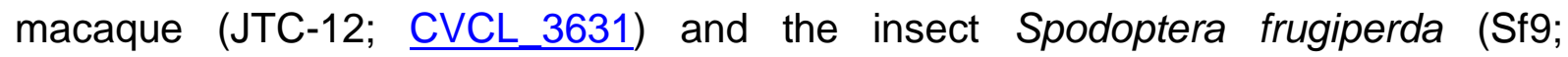
CVCL 0549). We have not been able to find any bird, reptile, amphibian or fish cellonaut.

In two cases we had difficulties to identify the exact cell line that was used on a space mission. The first case is what is reported by [Dickson, 1991] to be "Chinese hamster $L$ cell culture" and which was used in experiments carried by the Soviet Cosmos-782 satellite. But going back to the original report [Sushkov et al, 1977], we believe that this is what is often known as the mouse "L cells" (recommended name NCTC clone 929; CVCL 0462) which, in addition to being a very popular cell line is also famous for being the first ever established continuous cell line [Sanford et al, 1948].

The second case is quite puzzling and concerns an experiment, called CoCulture which flew on Shuttle STS-89 in January 1998, was transferred on the Russian Mir space station and was brought back on earth on STS-91 in June 1998. In a number of NASA documents including [W11] it is stated that "During the Biotechnology Coculture experiment conducted aboard Mir in the spring of 1998, breast carcinoma cells and endothelial cells were grown together in the Bioreactor Demonstration Unit. Principal investigators (PIs) Elliot Levine, of Wistar Institute, and Thomas Goodwin, of JSC, wanted to produce tumor tissue with blood vessel precursors". However we could not find in any publication or technical document any mention of the name of the two cell lines nor of the outcome of the experiment. By serendipity we could assign and identity to the "endothelial cells": in the 1970-90s Elliot Levine established a number of finite life human adult vascular endothelial cell lines. Some of them are still distributed by the Coriell Institute and one of them; HIVE-86 (also known under its Coriell assigned name: AG10773) contains the following sentence in a "Remarks" field [W13] "Microgravity experiment in space (Mission STS-89/Mir)". Thus most probably HIVE-86 is the "endothelial" cellonaut, but we were unable to pinpoint the identity of the breast carcinoma cell line. 
Many different types of cell lines have become cellonauts and the current roster includes 21 cancer cell lines, 16 spontaneously immortalized cell lines, 5 finite cell lines (2 fibroblasts, 2 fetal cell lines - including the famous WI-38 (CVCL 0579) used for vaccine production and 1 endothelial cell line), 4 hybridomas , 2 EBV-transformed cell lines, 2 SV-40 immortalized cell lines, one conditionally SV40 immortalized cell

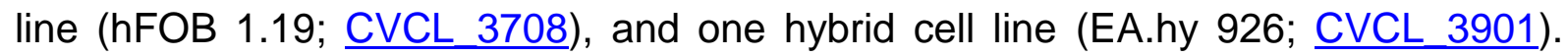
Embryonic stem cell lines do not yet seem to have made it to space. While the same seems true of induced pluripotent stem cells (iPSC), we found a publication [Li et al, 2019] reporting the study of embryoid bodies derived from two different mouse iPSCs in space during the Chinese Tianzhou-1 space mission.

In three instances contaminated cellonauts were flown in space without the knowledge of such contamination by the experimenters. The first instance is on the Zond-5 spacecraft in 1968. Along with HeLa, two other cell lines were flown on this mission [Zhukov-Verezhnikov et al, 1971]: CaVe (CVCL 8444) and a variant, CaVe K-10V ( CVCL WN72). CaVe was originally thought to be a gastric cancer cell line but is in fact contaminated by HeLa. So unknowingly Zond- 5 was carrying three different samples of HeLa! The second instance is much more recent and concerns $\mathrm{J}-111$ (CVCL 2965), also a HeLa contaminated cell line. J-111 was flown on the ISS in 2006 [Meloni et al, 2011]. While J-111 is known to be contaminated since 1968, the group that carried out this space experiment were still describing it as "a monocyte/macrophage cell line derived from human acute monocytic leukemia" in their 2011 publication. Finally, the third instance concerns MIP-101 (CVCL H689) which has flown on two Shuttle flights and on the ISS and which has very recently been shown to be a DLD-1 ( $\underline{\text { CVCL 0248) }}$ derivative.

We encountered one instance where a new variant of an existing cell line (rat L8; CVCL 4236) emerged during the space flight. It was called L8SF - for L8 Space Flown - ( $\underline{\text { CVCL WN49) }}$ [Kulesh et al, 1994]. There is also a publication reporting the sub-cloning of Ca Ski ( $\underline{\mathrm{CVCL} 1100})$ after a flight on Shenzou-8 [Yang et al, 2007] and reporting the characterization of 4 such sub-clones. While these two reports seem to be so far the only ones describing space "born" cellonauts, they are maybe other unreported births. For example, in the list of experiments that were planned to be carried out inside the German Spacelab module on the American shuttle flight STS-55 in 1993, the one untitled "Enhanced hybridoma production under microgravity" [W06] which was expected to produce new hybridomas using electrofusion. However we could not find any publication reporting the results of this experiment. Thus whether or not new hybridomas were generated on this space mission remains a mystery.

As it is apparent from the publication list in our table of cellonauts, many of the experiments that were carried out in space using cell lines produced publishable results on the effect of microgravity on quite a lot of biological processes such as cellular growth, protein secretion, DNA damage, cytoskeleton, apoptosis, etc. But in some cases technical problems precluded a successful outcome. One example are 
the experiments carried out on the ISS in 2001 on PC12 (CVCL 0481) and EMS-3 (CVCL WN68) as described in a NASA technical document [Robinson et al, 2006]: "There were problems in the growth and preservation of all of the cell lines grown on Expeditions 3 and 4. The PC12 and erythroleukemia cells did not survive well in long term culture, so no scientific results are expected from these experiments. "We found another example, concerning mouse C3H/10T1/2 clone 8 ( $\underline{\mathrm{CVCL} 0190)}$ ) as described from an ESA document [W17] "No results in microgravity were obtained due to a combination of malfunctioning hardware and unfulfilled temperature requirements."

Cellonauts did not always return safely on earth: a co-culture of LNCaP

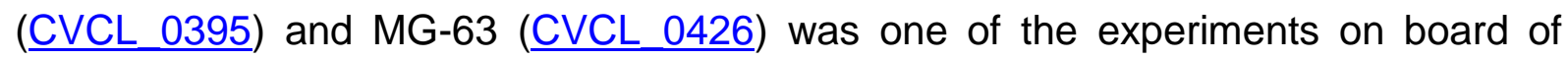
shuttle flight STS-107 [Wang et al, 2005]. The STS-107 mission flown on shuttle Columbia came to a tragic end on February 1, 2003 due to an in-flight break up during reentry into the atmosphere killing all 7 astronauts on board [W07].

The researchers preparing space flown biological experiments can also put themselves in danger. This was the case of two students, Georg Keller and Vlada Stamenkovic from the Zurich Space Biology Group at the Swiss Federal Institute of Technology [W18]. They had prepared an experiment to send pig chondrocytes (technically not cellonauts as these were primary cells) in space on the Russian Foton-M-1 unmanned space mission. On the 15th of October 2002, they were present at the Plesetsk launch complex when the rocket exploded 29 seconds after blastoff showering flaming debris over the launch area, killing one person and injuring 8 others [W19]. Fortunately the two students were not hurt, but they were quite shocked by this tragic event.

If you are interested in the backstage work implicated in the preparation of a cellonaut for a space flight, we encourage you to read the blog on Grimm's group website [W08] at the Otto-von-Guericke University Magdeburg in Germany. It describes the days that precede the launch on a Falcon-9 rocket of the Dragon resupply capsule that brought the CellBox-2 experiment to the ISS. CellBox-2 was designed to study the effect of microgravity on the transcriptome and proteome of the thyroid carcinoma cell line FTC-133 (

\section{Conclusion}

Next year will mark the $60^{\text {th }}$ anniversary of the first space flight of a cell line. While HeLa has been joined by 50 other cellonauts, we were surprised by their relative low number. One reason may be that, in addition to sounding rockets and parabolic flights there are a number of ground-based alternatives to space flight to study cells response to microgravity. Clinostats, rotating wall vessels (RWV) or random positioning machines (RPM) are devices that were developed to simulate the effect of microgravity [Anken, 2013; Herranz et al, 2013; Wuest et al, 2015; W09]. These devices are quite efficient while, as stated by Wuest et al "due to the extensive preparation effort, safety constraints and rare flight opportunities, however, access to space experiments is limited". 
As we are not expert in the field of microgravity research we probably have overlooked some Cellonauts and/or missed missions in which those listed in [Table 1] have participated. We therefore encourage reader to write to us so that we can correct and complete this mini-review.

\section{Acknowledgements}

We thank Amanda Capes-Davis for very useful feedback on various parts of this review. 
Table 1: List of known cellonauts and the space missions on which they were flown

\begin{tabular}{|c|c|c|c|c|}
\hline Cell line name & $\begin{array}{l}\text { Cellosaurus } \\
\text { ID }\end{array}$ & Species & Space flight(s) & Reference(s) \\
\hline 3G10G5 & CVCL WNOO & Mouse & Shuttle STS-77 & Smiley et al, 1997 \\
\hline 7E3-N & CVCL WN48 & Mouse & Shuttle STS-42 (Spacelab IML-1) & Bechler et al, 1993 \\
\hline AG01522 & CVCL H759 & Human & ISS Expedition 39 & Lu et al, 2017 \\
\hline AM2 & CVCL WN52 & Mouse & Shuttle STS-61A (Spacelab D-1) & Beaure d'Augeres et al, 1986 \\
\hline $\begin{array}{l}\text { B11d-ii-FAF } 28 \\
\text { clone } 237\end{array}$ & CVCL WN69 & Hamster & Cosmos-782 & Sushkov et al, 1977 \\
\hline B6MP102 & CVCL WN53 & Mouse & Shuttle STS-37, STS-43, STS-50 & Chapes et al, 1992; Chapes et al, 1994 \\
\hline BHK-21 & CVCL 1914 & Hamster & Cosmos-368 & Sushkov et al, 1976 \\
\hline $\begin{array}{l}\mathrm{C} 3 \mathrm{H} / 10 \mathrm{~T} 1 / 2 \\
\text { clone } 8\end{array}$ & CVCL 0190 & Mouse & Soyuz-TM-4/ISS Expedition 9/Soyuz-TM-3 & W17 \\
\hline Ca Ski & CVCL 1100 & Human & Shenzhou-4 & Yang et al, 2007 \\
\hline CaVe & $\overline{\text { CVCL } 8444}$ & Human & Zond-5 & Zhukov-Verezhnikov et al, 1971 \\
\hline CaVe K-10V & $\overline{\mathrm{CVCL}}$ WN72 & Human & Zond-5 & $\overline{\text { Zhukov-Verezhnikov et al, } 1971}$ \\
\hline EA.hy 926 & $\overline{\text { CVCL_3901 }}$ & Human & Shijian-10, CRS-8/ISS Expedition 47 & $\begin{array}{l}\underline{\text { Pietsch et al, 2017; }} \text { i Li et al, 2018; } \\
\underline{\underline{y}}\end{array}$ \\
\hline EMS-3 & CVCL WN68 & Mouse & ISS Expedition 4 & Robinson et al, 2006 \\
\hline FLC-707-02 & $\overline{C V C L} \quad$ WN4 7 & Mouse & Shuttle STS-42 (Spacelab IML-1) & $\overline{\text { Bechler et al, } 1993}$ \\
\hline FTC-133 & CVCL_1219 & Human & $\begin{array}{l}\text { Shenzhou-8, CRS-3/ISS Expedition 39, CRS-13/ISS } \\
\text { Expedition } 54\end{array}$ & $\begin{array}{l}\text { Pietsch et al, 2013; Ma et al, 2014; Riwaldt et } \\
\text { al, 2015; Melnik et al, } 2019\end{array}$ \\
\hline HaK & CVCL 3315 & Hamster & Shuttle STS-42 (Spacelab IML-1) & Lorenzi et al, 1993 \\
\hline HeLa & CVCL 0030 & Human & $\begin{array}{l}\text { Korabl-Sputnik-2, Vostok-1, Vostok-4, Vostok-5, Vostok-6, } \\
\text { Voskhod-1, Zond-5, Discoverer XVIII, Progress M- } \\
\text { 35/Mir/Soyuz-TM-25, Shuttle STS-89/Mir }\end{array}$ & $\begin{array}{l}\text { Dickson, 1991; Katzberg, 1962; } \text { Ohnishi et al, } \\
\underline{2002}\end{array}$ \\
\hline hFOB 1.19 & CVCL 3708 & Human & Shuttle STS-80 & Harris et al, 2000 \\
\hline HIVE-86 & $\overline{\mathrm{CVCL}}$ 0E19 & Human & Shuttle STS-89/Mir/STS-91 & W11; W12;W13 \\
\hline $\mathrm{HL}-60$ & $\overline{\mathrm{CVCL}} 00002$ & Human & Shuttle STS-67, STS-86/Mir, STS-90 & Piepmeier et al, $1997 ; \underline{\text { W10 }}$ \\
\hline HL-60/AR & CVCL WR 44 & Human & Shuttle STS-67 & Piepmeier et al, 1997 \\
\hline $\mathrm{J}-111$ & CVCL 2965 & Human & ISS Expedition 13 & Meloni et al, 2011 \\
\hline JC-1 & CVCL WN03 & Human & Shuttle STS-47 (Spacelab-J) & Suganuma et al, 2001 \\
\hline JTC-12 & CVCL 3631 & Macaque & Shuttle STS-47 (Spacelab-J) & Sato, 1993; Sato et al, 2001 \\
\hline Jurkat & CVCL 0065 & Human & Cosmos-2044 & Limouse et al, 1991 \\
\hline Jurkat E6.1 & $\overline{C V C L} \quad 0367$ & Human & Shuttle STS-76, STS-80, STS-95 & $\begin{array}{l}\text { Lewis et al, 1998; Cubano et al, 2000; Lewis et } \\
\text { al, 2001; Schatten et al, } 2001\end{array}$ \\
\hline L-M & CVCL 4535 & Mouse & Shuttle STS-50 (USML-1), STS-54, STS-57 (Spacehab-1) & Woods \& Chapes, 1994 \\
\hline
\end{tabular}




\begin{tabular}{|c|c|c|c|c|}
\hline L8 & CVCL 4236 & Rat & Shuttle STS-45, STS-63 & Kulesh et al, 1994; W14 \\
\hline L8SF & $\overline{\text { CVCL WN } 49}$ & Rat & Shuttle STS-45 & Kulesh et al, 1994 \\
\hline LN1 & CVCL 9U28 & Human & ISS Expedition 3 & Hammond et al, 2005 \\
\hline LNCaP & $\overline{\text { CVCL } 0395}$ & Human & Shuttle STS-107 & Wang et al, 2005 \\
\hline MC3T3-E1 & CVCL 0409 & Mouse & Shuttle STS-56, STS-76, STS-81, STS-84 & $\begin{array}{l}\text { Hughes-Fulford \& Lewis, 1996; Hughes- } \\
\text { Fulford, } 2001\end{array}$ \\
\hline MCF-7 & CVCL 0031 & Human & Foton-12 & Vassy et al, 2001; Vassy et al, 2003 \\
\hline MG-63 & CVCL 0426 & Human & $\begin{array}{l}\text { Shuttle STS-107, Foton-10, Foton-M3, ISS Expeditions 47- } \\
50\end{array}$ & $\begin{array}{l}\text { Carmeliet et al, 1997; Carmeliet et al, 1998; } \\
\text { Wang et al, 2005; Guignandon et al, 2014; } \underline{\text { W15 }}\end{array}$ \\
\hline MIP-101 & CVCL H689 & Human & Shuttle STS-70, STS-85, ISS Expedition 3 & Jessup et al, 2000; Robinson et al, 2006 \\
\hline MLO-Y4 & CVCL M098 & Mouse & Tianzhou-1 & Gao et al, 2018 \\
\hline MN7 & $\overline{\text { CVCL WS } 46}$ & Mouse & Cosmos-2229 (Bion-10) & Bierkens et al, 1994; Berezovskaia et al, 1998 \\
\hline $\begin{array}{l}\text { NCTC clone } \\
929 \text { ( } \mathrm{L} \text { cells) }\end{array}$ & CVCL_0462 & Mouse & Cosmos-782 & Sushkov et al, 1977 \\
\hline NHF-23 & CVCL WN76 & Human & Shuttle STS-65 (Spacelab IML-2) & Horneck et al, 1997 \\
\hline NR8383 & $\overline{\text { CVCL } 4396}$ & Rat & CRS-6/ISS Expedition 43 & Thiel et al, 2017 \\
\hline PC12 & $\overline{\text { CVCL } 0481}$ & Rat & Shuttle STS-86/Mir, ISS Expedition 3 & Unsworth et al, 1998; Robinson et al, 2006 \\
\hline PICM-19 & CVCL V146 & Pig & Shuttle STS-126 & Talbot et al, 2010 \\
\hline ROS 17/2.8 & $\overline{\text { CVCL } 0508}$ & Rat & Cosmos-2229 (Bion-10), Foton-11, Foton-12 & Guignandon et al, 1997; Guignandon et al, \\
\hline Sf9 & CVCL 0549 & $\begin{array}{l}\text { Fall } \\
\text { armyworm }\end{array}$ & Shuttle STS-50 (USML-1), STS-54, STS-57 (Spacehab-1) & Moos et al, 1994 \\
\hline THP-1 & CVCL 0006 & Human & Cosmos-2044 & Limouse et al, 1991 \\
\hline TSCE5 & CVCL WN50 & Human & STS-126/ISS Expedition 18/STS-119 & Takahashi et al, 2010; Yatagai et al, 2011 \\
\hline U-937 & CVCL 0007 & Human & Shuttle STS-76, Shenzhou-8 & Hatton et al, 1999; Paulsen et al, 2013 \\
\hline V79-4 & CVCL 2796 & Hamster & Salyut-6/Soyuz-31 & Dickson, 1991; W16 \\
\hline WB-F344 & $\overline{\text { CVCL } 9806}$ & Rat & Tianzhou-1 & Gao et al, 2018 \\
\hline WI-26 & CVCL V826 & Human & ISS Expeditions 47-50 & W15 \\
\hline WI-38 & CVCL 0579 & Human & Skylab-3 & Montgomery et al, 1978 \\
\hline WTK-1 & $\overline{\text { CVCL_6742 }}$ & Human & STS-126/ISS Expedition 18/STS-119 & Takahashi et al, 2010 \\
\hline
\end{tabular}




\section{References}

\section{A) Publications}

Anken A.; Simulation of microgravity for studies in gravitational biology: principles, devices and applications; Current Biotechnol. 2:192-200(2013) [DOI=10.2174/22115501113029990012]

Bairoch A.; The Cellosaurus, a cell line knowledge resource; J. Biomol. Tech. 29:25-38(2018) [DOI=10.7171/jbt.18-2902-002]

Beaure d'Augeres C., Arnoult J., Bureau J., Duie P., Dupuy-Coin A.M., Geraud G., Laquerriere F., Masson C., Pestmal M., Bouteille M.; Effect of microgravity on mammalian cell polarization at the ultrastructural level; Naturwissenschaften 73:407409(1986) [DOI=10.1007/BF00367280

Bechler B., Hunzinger E., Muller O., Cogoli A.; Culture of hybridoma and Friend leukemia virus transformed cells in microgravity. Spacelab IML-1 mission; Biol. Cell 79:45-50(1993) [DOI=10.1016/0248-4900(93)90261-C].

Berezovskaia O.P., Rodionova N.V.; The effect of microgravity on osteogenic cells in culture. Ultrastructural research; Tistol. Genet. 32:3-8(1998) [PubMed=9813886]

Bierkens J., Maes J., Ooms D., Collier M., Vangenechten C., Borremans B., van Vlasselaer P., Schoeters G.; Decreased acquisition of osteoblastic phenotype markers and increased response to interleukin-1 and parathyroid hormone in pre-osteoblast like cells under microgravity; (In) Life sciences research in space. Proceedings of the fifth European symposium held 26 September-1 October 1993 in Arcachon France, ESA SP-366; Oser H., Guyenne T.D. (eds.); pp.25-30; European Space Agency; Noordwijk (1994) [http://articles.adsabs.harvard.edu/full/1994ESASP.366...25B]

Carmeliet G., Nys G., Bouillon R.; Microgravity reduces the differentiation of human osteoblastic MG-63 cells; J. Bone Miner. Res. $12: 786-794(1997)[\mathrm{DOI}=10.1359 / \mathrm{jbmr}$.1997.12.5.786]

Carmeliet G., Nys G., Stockmans I., Bouillon R.; Gene expression related to the differentiation of osteoblastic cells is altered by microgravity; Bone 22:139S-143S(1998) [DOI=10.1016/S8756-3282(98)00007-6]

Chapes S.K., Morrison D.R., Guikema J.A., Lewis M.L., Spooner B.S.; Cytokine secretion by immune cells in space; J. Leukoc. Biol. 52:104-110(1992) [DOI=10.1002/jlb.52.1.104]

Chapes S.K., Morrison D.R., Guikema J.A., Lewis M.L., Spooner B.S.; Production and action of cytokines in space; Adv. Space Res. 14:5-9(1994) [DOI=10.1016/0273-1177(94)90380-8]

Cubano L.A., Lewis M.L.; Fas/APO-1 protein is increased in spaceflown lymphocytes (Jurkat); Exp. Gerontol. 35:389-400(2000) [DOI $=\underline{10.1016 / \mathrm{S} 0531-5565(00) 00090-5]}$

Dickson K.J.; Summary of biological spaceflight experiments with cells; ASGSB Bull. 4:151-260(1991) [PubMed=11537177]

Gao M., Zhao G.-H., Gu Y.-D.; Progress of space sciences and application projects in China's manned space flight; (In) Space Science Activities in China: National Report 2016-2018, pp.22-43 (2018) [http://english.cssar.cas.cn/ns/NU/201809/W020180906583001262971.pdf]

Guignandon A., Genty C., Vico L., Lafage-Proust M.-H., Palle S., Alexandre C.; Demonstration of feasibility of automated osteoblastic line culture in space flight; Bone 20:109-116(1997) [DOI=10.1016/S8756-3282(96)00337-7]

Guignandon A., Lafage-Proust M.-H., Usson Y., Laroche N., Caillot-Augusseau A., Alexandre C., Vico L.; Cell cycling determines integrin-mediated adhesion in osteoblastic ROS 17/2.8 cells exposed to space-related conditions; FASEB J. 15:2036-2038(2001) $[\mathrm{DOI}=\underline{10.1096 / \mathrm{fj} .00-0837 \mathrm{fje}]}$

Guignandon A., Faure C., Neutelings T., Rattner A., Mineur P., Linossier M.-T., Laroche N., Lambert C., Deroanne C., Nusgens B., Demets R., Colige A., Vico L.; Rac1 GTPase silencing counteracts microgravity-induced effects on osteoblastic cells; FASEB J. 28:4077-4087(2014) [DOI=10.1096/fi.14-249714]

Hammond D.K., Becker J.L., Elliott T.F., Holubee K., Baker T.L., Love J.E.; Antigenic protein in microgravity-grown human mixed Mullerian ovarian tumor (LN1) cells preserved in RNA stabilizing agent; Gravit. Space Biol. Bull. 18:99-100(2005) [PubMed $=\underline{16044626}$ ] 
Harris S.A., Zhang M., Kidder L.S., Evans G.L., Spelsberg T.C., Turner R.T.; Effects of orbital spaceflight on human osteoblastic cell physiology and gene expression; Bone 26:325-331(2000) [DOI=10.1016/S8756-3282(00)00234-9]

Hatton J.P., Gaubert F., Lewis M.L., Darsel Y., Ohlmann P., Cazenave J.-P., Schmitt D.; The kinetics of translocation and cellular quantity of protein kinase $C$ in human leukocytes are modified during spaceflight; FASEB J. 13:S23-S33(1999). [DOI=10.1096/fasebj.13.9001.s23]

Herranz R., Anken R., Boonstra J., Braun M., Christianen P.C.M., de Geest M., Hauslage J., Hilbig R., Hill R.J.A., Lebert M., Medina F.J., Vagt N., Ullrich O., van Loon J.J.W.A., Hemmersbach R.; Ground-based facilities for simulation of microgravity: organism-specific recommendations for their use, and recommended terminology; Astrobiology 13:1-17(2013) $[\mathrm{DOI}=\underline{10.1089 / \text { ast.2012.0876] }}$

Horneck G., Rettberg P., Kozubek S., Baumstark-Khan C., Rink H., Schafer M., Schmitz C.; The influence of microgravity on repair of radiation-induced DNA damage in bacteria and human fibroblasts; Radiat. Res. 147:376-384(1997) [DOI=10.2307/3579347]

Hughes-Fulford M., Lewis M.L.; Effects of microgravity on osteoblast growth activation; Exp. Cell Res. 224:103-109(1996) $[\mathrm{DOI}=\underline{10.1006 / \mathrm{excr} .1996 .0116]}$

Hughes-Fulford M.; Changes in gene expression and signal transduction in microgravity; J. Gravit. Physiol. 8:P1-P4(2001) [PubMed $=\underline{12638602]}$

Isakeit D., Sabbatini M., Carey W.; Sharing ESA's knowledge and experience -- the Erasmus Experiment Archive; ESA bulletin 120:34-39(2004) [https://www.researchgate.net/publication/234213901]

Jessup J.M., Frantz M., Sonmez-Alpan E., Locker J., Skena K., Waller H., Battle P., Nachman A., Weber M.E., Thomas D.A., Curbeam R.L. Jr., Baker T.L., Goodwin T.J.; Microgravity culture reduces apoptosis and increases the differentiation of a human colorectal carcinoma cell line; In Vitro Cell. Dev. Biol. Anim. 36:367-373(2000) [DOI= 10.1290/10712690(2000)036<0367:MCRAAl>2.0.CO;2]

Katzberg A.A.; The effect of space flights on living human cells aboard Discoverer XVIII; Tech. Doc. Rep. SAMTDR USAF Sch. Aerosp. Med. 62-43:1-4(1962) [PubMed=14031339]

Kruger M., Pietsch J., Bauer J., Kopp S., Carvalho D.T.O., Baatout S., Moreels M., Melnik D., Wehland M., Egli M., Jayashree S., Kobbero S.D., Corydon T.J., Nebuloni S., Gass S., Evert M., Infanger M., Grimm D.; Growth of endothelial cells in space and in simulated microgravity -- a comparison on the secretory level; Cell. Physiol. Biochem. 52:1039-1060(2019) $[\mathrm{DOl}=\underline{10.33594 / 000000071]}$

Kulesh D.A., Anderson L.H., Wilson B., Otis E.J., Elgin D.M., Barker M.J., Mehm W.J., Kearney G.P.; Space shuttle flight (STS-45) of L8 myoblast cells results in the isolation of a nonfusing cell line variant; J. Cell. Biochem. 55:530-544(1994) [DOI $=\underline{10.1002 / j \mathrm{cb} .240550412]}$

Lewis M.L., Reynolds J.L., Cubano L.A., Hatton J.P., Lawless B.D., Piepmeier E.H.; Spaceflight alters microtubules and increases apoptosis in human lymphocytes (Jurkat); FASEB J. 12:1007-1018(1998) [DOI=10.1096/fasebj.12.11.1007]

Lewis M.L., Cubano L.A., Zhao B., Dinh H.-K., Pabalan J.G., Piepmeier E.H., Bowman P.D.; cDNA microarray reveals altered cytoskeletal gene expression in space-flown leukemic T lymphocytes (Jurkat); FASEB J. 15:1783-1785(2001) [DOI=10.1096/fi.000820fje]

Li N., Wang C.-Z., Sun S.-J., Zhang C., Lu D.-Y., Chen Q., Long M.; Microgravity-induced alterations of inflammation-related mechanotransduction in endothelial cells on board SJ-10 satellite; Front. Physiol. 9:1025-1025(2018) $[\mathrm{DOI}=\underline{10.3389 / \mathrm{fphys} .2018 .01025]}$

Li H., Zhu H.-M., Zhang F.-Z., Dong X.-H., Hao T., Jiang X.-X., Zheng W.-B., Zhang T., Chen X., Wang P.-Z., Na J., Wang C.-Y., Zhou J.; Spaceflight promoted myocardial differentiation of induced pluripotent stem cells: results from Tianzhou-1 space mission; Stem Cells Dev. 28:357-360(2019) [DOI=10.1089/scd.2018.0240]

Limouse M., Manie S., Konstantinova I., Ferrua B., Schaffar L.; Inhibition of phorbol ester-induced cell activation in microgravity; Exp. Cell Res. 197:82-86(1991) [DOI=10.1016/0014-4827(91)90482-A]

Lorenzi G., Gmunder F.K., Cogoli A.; Cultivation of hamster kidney cells in a dynamic cell culture system in space (Spacelab IML-1 mission); Microgravity Sci. Technol. 6:34-38(1993). [PubMed=11541489] 
Lu T., Zhang Y., Kidane Y., Feiveson A., Stodieck L., Karouia F., Ramesh G., Rohde L., Wu H.; Cellular responses and gene expression profile changes due to bleomycin-induced DNA damage in human fibroblasts in space; PLoS ONE 12:E0170358E0170358(2017) [DOI=10.1371/journal.pone.0170358]

Ma X., Pietsch J., Wehland M., Schulz H., Saar K., Hubner N., Bauer J., Braun M., Schwarzwalder A., Segerer J., Birlem M., Horn A., Hemmersbach R., Wasser K., Grosse J., Infanger M., Grimm D.; Differential gene expression profile and altered cytokine secretion of thyroid cancer cells in space; FASEB J. 28:813-835(2014) [DOI=10.1096/fj.13-243287]

Melnik D., Krüger M., Kopp S., Wehland M., Bauer J., Infanger M., Grimm D.; Microgravity-based modulation of VEGF expression in human thyroid carcinoma cells; Front. Physiol. Conference Abstract: 39th ISGP Meeting \& ESA Life Sciences Meeting (2019) [DOI $=$ 10.3389/conf. .fphys.2018.26.00002]

Meloni M.A., Galleri G., Pani G., Saba A., Pippia P., Cogoli-Greuter M.; Space flight affects motility and cytoskeletal structures in human monocyte cell line J-111; Cytoskeleton 68:125-137(2011) [DOI=10.1002/cm.20499]

Montgomery P.O. Jr., Cook J.E., Reynolds R.C., Paul J.S., Hayflick L., Stock D., Schulz W.W., Kimsey S., Thirolf R.G., Rogers T., Campbell D.; The response of single human cells to zero gravity; In Vitro 14:165-173(1978) [DOI=10.1007/BF02618218]

Moore D., Cogoli A.; Gravitational and space biology at the cellular level; (In) Biological and medical research in space. An overview of life sciences research in microgravity; Moore D., Bie P., Oser H. (eds.); pp.1-106; Springer; Berlin (1996) $[\mathrm{DOI}=\underline{10.1007 / 978-3-642-61099-8} \quad 1]$

Moos P.J., Fattaey H.K., Johnson T.C.; Cell proliferation inhibition in reduced gravity; Exp. Cell Res. 213:458-462(1994) [DOI $=\underline{10.1006 / \text { excr.1994.1223] }}$

Ohnishi T., Ohnishi K., Takahashi A., Taniguchi Y., Sato M., Nakano T., Nagaoka S.; Detection of DNA damage induced by space radiation in Mir and space shuttle; J. Radiat. Res. 43:S133-S136(2002) [DOI=10.1269/jrr.43.s133]

Paulsen K., Tauber S., Goelz N., Simmet D.M., Engeli S., Birlem M., Dumrese C., Karer A., Hunziker S., Biskup J., Konopasek S., Suh D., Hurlimann E., Signer C., Wang A., Sang C., Grote K.-H., Zhuang F.-Y., Ullrich O.; Severe disruption of the cytoskeleton and immunologically relevant surface molecules in a human macrophageal cell line in microgravity -- results of an in vitro experiment on board of the Shenzhou-8 space mission; Acta Astronaut. 94:277-292(2013) [DOI=10.1016/j.actaastro.2013.06.007]

Piepmeier E.H., Kalns J.E., Mclntyre K.M., Lewis M.L.; Prolonged weightlessness affects promyelocytic multidrug resistance; Exp. Cell Res. 237:410-418(1997) [DOI=10.1006/excr.1997.3813]

Pietsch J., Ma X., Wehland M., Aleshcheva G., Schwarzwalder A., Segerer J., Birlem M., Horn A., Bauer J., Infanger M., Grimm D.; Spheroid formation of human thyroid cancer cells in an automated culturing system during the Shenzhou-8 Space mission; Biomaterials 34:7694-7705(2013) [DOI=10.1016/j.biomaterials.2013.06.054]

Pietsch J., Gass S., Nebuloni S., Echegoyen D., Riwaldt S., Baake C., Bauer J., Corydon T.J., Egli M., Infanger M., Grimm D.; Three-dimensional growth of human endothelial cells in an automated cell culture experiment container during the SpaceX CRS-8 ISS space mission -- The SPHEROIDS project; Biomaterials 124:126-156(2017) [DOI=10.1016/j.biomaterials.2017.02.005]

Ray S., Gebre S., Fogle H., Berrios D.C., Tran P.B., Galazka J.M., Costes S.V.; GeneLab: Omics database for spaceflight experiments; Bioinformatics 35:1753-1759(2019) [DOI=10.1093/bioinformatics/bty884]

Rees J.M., King-Hele D.G.; Table of the artificial earth satellites launched in 1957-1962; Planet. Space Sci. 11:1053-1081(1963) $[\mathrm{DOI}=\underline{10.1016 / 0032-0633(63) 90042-4]}$

Riwaldt S., Pietsch J., Sickmann A., Bauer J., Braun M., Segerer J., Schwarzwalder A., Aleshcheva G., Corydon T.J., Infanger M., Grimm D.; Identification of proteins involved in inhibition of spheroid formation under microgravity; Proteomics 15:2945-2952(2015) [DOI=10.1002/pmic.201500067]

Robinson J.A., Rhatigan J.L., Baumann D.K., Tate J., Thumm T.; International Space Station Research Summary through Expedition 10; NASA/TP 2006-213146 [https://ston.jsc.nasa.gov/collections/TRS/ techrep/TP-2006-213146.pdf]

Sanford K.K., Earle W.R., Likely G.D.; The growth in vitro of single isolated tissue cells; J. Natl. Cancer Inst. 9:229-246(1948) [DOI=10.1093/jnci/9.3.229]

Sato A.; Mammalian cells in space weightlessness; Uchu Seibutsu Kagaku 6:147-153(1993) [DOI=10.2187/bss.6.147] 
Sato A., Kumei Y., Sato K., Hongo T., Hamazaki T., Masuda I., Nakajima T., Ohmura T., Kaiho M., Sato T., Wake K.; Studies on the effects of microgravity on the ultrastructure and function of cultured mammalian cells; Uchu Seibutsu Kagaku 15:S61-S63(2001) $[$ PubMed $=\underline{12101351]}$

Schatten H., Lewis M.L., Chakrabarti A.; Spaceflight and clinorotation cause cytoskeleton and mitochondria changes and increases in apoptosis in cultured cells; Acta Astronaut. 49:399-418(2001) [DOI=10.1016/S0094-5765(01)00116-3]

Skloot R.; The immortal life of Henrietta Lacks; Random House; New York (2010) [ISBN=9781400052172]

Smiley S.A., Gillock E.T., Black M.C., Consigli R.A.; The effect of space flight on monoclonal antibody synthesis in a hybridoma mouse cell line; Exp. Cell Res. 230:411-414(1997) [DOI=10.1006/excr.1996.3445]

Suganuma T., O'oka H., Fukuda T.; Study of the effects of microgravity on cell growth of human antibody producing cells and their secretions; Uchu Seibutsu Kagaku 15:S64-S66(2001) [PubMed=12101352]

Sushkov F.V., Portugalov V.V., Rudneva S.V., Bobkova N.N., Iordanishvili E.K., Izupak E.A.; Results of mammalian cell culture exposure on artificial earth satellites; Kosm. Biol. Aviakosm. Med. 10:58-63(1976) [PubMed=1263417]

Sushkov F.V., Rudneva S.V., Nadtochei G.A., Polikarpova S.I., Portugalov V.V.; Experiments with cultures of mammalian cells aboard the biosatellite 'Cosmos-782'; Arkh. Anat. Gistol. Embriol. 73:28-39(1977) [PubMed=563224]

Takahashi A., Suzuki H., Omori K., Seki M., Hashizume T., Shimazu T., Ishioka N., Ohnishi T.; The expression of p53-regulated genes in human cultured lymphoblastoid TSCE5 and WTK1 cell lines during spaceflight; Int. J. Radiat. Biol. 86:669-681(2010) [DOI $=\underline{10.3109 / 09553001003789596]}$

Talbot N.C., Caperna T.J., Blomberg L.A., Graninger P.G., Stodieck L.S.; The effects of space flight and microgravity on the growth and differentiation of PICM-19 pig liver stem cells; In Vitro Cell. Dev. Biol. Anim. 46:502-515(2010) [DOI=10.1007/s11626-0109302-6]

Thiel C.S., de Zelicourt D., Tauber S., Adrian A., Franz M., Simmet D.M., Schoppmann K., Hauschild S., Krammer S., Christen M., Bradacs G., Paulsen K., Wolf S.A., Braun M., Hatton J., Kurtcuoglu V., Franke S., Tanner S., Cristoforetti S., Sick B., Hock B., Ullrich O.; Rapid adaptation to microgravity in mammalian macrophage cells; Sci. Rep. 7:43-43(2017) [DOI=10.1038/s41598-017$\underline{00119-6]}$

Unsworth B.R., Lelkes P.I.; Growing tissues in microgravity; Nat. Med. 4:901-907(1998) [DOI=10.1038/nm0898-901]

Vassy J., Portet S., Beil M., Millot G., Fauvel-Lafeve F., Karniguian A., Gasset G., Irinopoulou T., Calvo F., Rigaut J.P., Schoevaert D.; The effect of weightlessness on cytoskeleton architecture and proliferation of human breast cancer cell line MCF-7; FASEB J. $15: 1104-1106(2001)[\mathrm{DOI}=\underline{10.1096 / \mathrm{fj} .00-0527 \mathrm{fje}]}$

Vassy J., Portet S., Beil M., Millot G., Fauvel-Lafeve F., Gasset G., Schoevaert D.; Weightlessness acts on human breast cancer cell line MCF-7; Adv. Space Res. 32:1595-1603(2003) [DOI=10.1016/S0273-1177(03)90400-5]

Wang R., Xu J., Juliette L., Castilleja A., Love J., Sung S.Y., Zhau H.E., Goodwin T.J., Chung L.W.; Three-dimensional co-culture models to study prostate cancer growth, progression, and metastasis to bone; Semin. Cancer Biol. 15:353-364(2005) $[\mathrm{DOI}=\underline{10.1016 / \mathrm{i} . \text { semcancer.2005.05.005] }}$

Woods K.M., Chapes S.K.; Abrogation of TNF-mediated cytotoxicity by space flight involves protein kinase C; Exp. Cell Res. 211:171-174(1994) [DOI=10.1006/excr.1994.1074]

Wuest S.L., Richard S., Kopp S., Grimm D., Egli M.; Simulated microgravity: critical review on the use of random positioning machines for mammalian cell culture; Biomed. Res. Int. 2015:971474-971474(2015) [DOI=10.1155/2015/971474]

Yang C., Li G.-C., Li Y.-H., Hu J.-Y., Xiao Y., Zhang Z.-J.; Biological properties of Caski cell lines induced by exposing to the space environment; Zhong Nan Da Xue Xue Bao Yi Xue Ban 32:380-386(2007) [PubMed=17611311]

Yatagai F., Honma M., Takahashi A., Omori K., Suzuki H., Shimazu T., Seki M., Hashizume T., Ukai A., Sugasawa K., Abe T., Dohmae N., Enomoto S., Ohnishi T., Gordon A., Ishioka N.; Frozen human cells can record radiation damage accumulated during space flight: mutation induction and radioadaptation; Radiat. Environ. Biophys. 50:125-134(2011) [DOI=10.1007/s00411-010-03483] 
Zhukov-Verezhnikov N.N., Volkov M.N., Maisky I.N., Rybakov N.I., Guberniev M.A., Podoplelov I.I., Kulagin A.N., Aniskin E.D., Rybakova K.D., Sharyi N.I., Voronkova I.P., Saxonov P.P., Kopyev V.Y., Antipov V.V., Kozlov V.A., Parfyonov G.P., Orlovsky V.I.; Experiments with micro-organisms and human cell cultures in the Zond 5 and Zond 7 flights; Life Sci. Space Res. 9:99-103(1971) [PubMed $=\underline{11942358]}$

\section{B) Web references}

[W01] https://en.wikipedia.org/wiki/Korabl-Sputnik 2

[W02] https://en.wikipedia.org/wiki/Sputnik 2

[W03] https://www.theatlantic.com/technology/archive/2012/12/who-was-first-in-the-race-to-the-moon-the-tortoise/266665/

[W04] https://en.wikipedia.org/wiki/Discoverer 18

[W05] https://en.wikipedia.org/wiki/Corona (satellite)

[W06] https://science.ksc.nasa.gov/shuttle/missions/sts-55/sts-55-press-kit.txt

[W07] https://en.wikipedia.org/wiki/Space Shuttle Columbia disaster

[W08] http://www.grimm-space-research.com/page4/Blog/Blog Cellbox-2.html

[W09] http://www.grimm-space-research.com/RPM/RPM.html

[W10] https://ntrs.nasa.gov/archive/nasa/casi.ntrs.nasa.gov/20030061293.pdf

[W11] https://www.hq.nasa.gov/office/hqlibrary/documents/045786017 1998.pdf

[W12] https://history.nasa.gov/SP-4225/science/issphase1sci.pdf

[W13] https://www.coriell.org/0/Sections/Search/Sample Detail.aspx?Ref=AG10773\&Pgld=166

[W14] https://lsda.jsc.nasa.gov/Experiment/exper/665

[W15] https://www.nasa.gov/mission pages/station/research/experiments/explorer/Investigation.html?\#id=1702

[W16] https://ntrs.nasa.gov/archive/nasa/casi.ntrs.nasa.gov/19860013747.pdf

[W17] http://eea.spaceflight.esa.int/portal/exp/?id=6937

[W18] http://archiv.ethlife.ethz.ch/articles/Rakete.html

[W19] http://www.russianspaceweb.com/foton.html 